\title{
PATHWAYS TO IMPROVE ENERGY EFFICIENCY AND MINIMIZE ENVIRONMENTAL FOOTPRINTS OF GHG EMISSION OF ENERGY INPUTS USED IN COWPEA PRODUCTION IN NIGER STATE OF NIGERIA
}

\author{
M.S. Sadiq ${ }^{1}$ I.P. Singh ${ }^{2}$ and N. Karunakaran ${ }^{3}$ \\ ${ }^{I}$ Department of Agricultural Economics and Extension Technology, Federal University of Technology, Nigeria \\ ${ }^{2}$ Department of Agricultural Economics, Swami Keshwanand Rajasthan Agricultural University, India \\ ${ }^{3}$ Department of Economics, EK Nayanar Memorial Government College, India
}

\begin{abstract}
Increasing population level and food demand around the world has made producers and policy makers to utilize scientific models and techniques for taking sustainability into consideration. Energy as an important ingredient in all production systems has been focused for the production process of cowpea in Niger State of Nigeria. The study investigated optimal input use for cowpea producers using Data Envelopment Analysis (DEA) approach. The analysis found that 14 and 19 units are efficient in CCR and BCC models, respectively, and mean values of technical efficiency, pure technical efficiency and scale efficiency scores were $0.86,0.90$ and 0.96 , respectively. Manure, inorganic fertilizers and biocides were identified as the most inefficient inputs used. The results also revealed that approximately $28.37 \%$ of total energy input resources can be saved if the farmers follow the input package recommended by the DEA and by energy optimization total GHG emission can be reduced. Policies should emphasize on development of new technologies to substitute agro-chemical with renewable energy sources towards efficient energy use and lowering environmental footprints of GHG emissions resulting in sustainable food production systems.
\end{abstract}

Keywords:

Energy, Efficiency, GHG Emission, DEA, Cowpea, Niger

\section{INTRODUCTION}

One of the five global problems is the threat of a long-run increase in the surface temperature of the earth. Global warming must be considered on an entirely different scale from that of most other environmental issues. The effects of global warming, or 'greenhouse effect' as it is popularly called, are long-term and largely irreversible. However, as a result of increased human activities, more and more of these greenhouse gases are released into the atmosphere. This leads to the greenhouse gases becoming thicker and upsets the natural greenhouse effect. Global warming and climate change are emerging as serious threats to the sustainability of natural environment, farming, as well as all forms of life. To meet this challenge, development programmes must have built-in provision for mitigating the impact of global warming and climate change. The worst impact is on agriculture and ecosystems, because it results in substantial decline in soil moisture due to high temperature and variability in rainfall besides the increased pest and weed growth promoted by higher $\mathrm{CO}_{2}$ concentration in the areas that are the world's bread baskets. Altered rainfall is the most unpredictable and deleterious effect of greenhouse related climate change on agriculture.

The consequences of global warming clearly indicate that both developed and developing nations have good reason to worry about global warming, and, global cooperation is an important consideration when addressing global warming issues. In line with this, the responses to global warming can be analysed as technical response and policy response. Technical response attempts at reducing emission of greenhouse gases and increasing the $\mathrm{CO}_{2}$ absorbing capacity of the earth, while the policy option is carbon tax, a tool expected to provide an incentive to reduce fuel, agrochemical, etc. and to shift to lower carbon forms of energy. Besides these technological and policy options, a worldwide cooperation is required to prevent further warming of the globe to reduce emissions of the greenhouse gases. The formation of the inter-governmental panel of climate change (IPCC) in 1988 is an attempt at achieving this global cooperation. The second world climate conference of 1990 concluded that nations should take steps to reduce greenhouse gases at source. The Kyoko protocol is yet another milestone in attempt to reduce global warming. Meanwhile, sustainability has received peculiar attention due to the growing number of population and correspondingly energy demand. One of the useful methods to evaluate and investigate the potential long-term sustainability of agricultural practices is energy auditing and its analysis [12] However, no study was found about technical efficiency measurement of cowpea production farms in the light of energy efficiency and GHG emission reduction using data envelopment analysis.

In this study, DEA was used with the objectives to quantify the energy use in cowpea product relative to the energy invested in its production, rank efficient and inefficient ones, identify target energy requirements and wasteful uses of energy from different inputs, and determine the effect of energy optimization on GHG emission in cowpea production in Niger State of Nigeria.

\section{LITERATURE REVIEW}

In the literature review, studies which applied DEA to investigate GHG emission reduction in agricultural units in different countries on crop production and animal husbandry are few, and examples of such studies are Komleh et al. [12], Komleh et al. [13], Khoshnevisan et al. [5], Khoshnevisan et al. [6], Soni et al. [19], Pelesaraei et al. [9], Kordkheili et al. [14], Sadiq et al. [16], Sadiq et al. [15], Sadiq et al. [17], Onuk et al. [11], Singh and Mukhi [18], Carvalho et al. [7] and Kyei et al. [20].

\section{METHODOLOGY}

Niger State is an agrarian state in Nigeria and has been in the forefront of food crops production. The present study made use of 
multi stage sampling technique to collect cross sectional data fortnightly during 2015 cropping season from a total sample size of 40 active cowpea producers. Firstly, one agricultural zone, namely Kontagora zone out of the three agricultural zones in the state was chosen as a representative of cowpea production enterprise since it is the main center of cowpea production in the state, due to the very favourable ecological conditions. Secondly, two LGAs namely Mashegu and Mariga, were randomly selected. Thirdly, two villages from each selected LGAs were randomly selected. Lastly, ten respondents from each selected villages were randomly selected, given a total sampling size of 40 farmers. Instrument for data collection were structured questionnaire coupled with interview schedule. Data Envelopment Analysis (DEA) was used to analyze data.

\subsection{EMPIRICAL MODEL-DATA ENVELOPMENT ANALYSIS (DEA)}

The DEA is a non-parametric data analytic technique whose domain of inquiry is a set of entities, commonly called decisionmaking units (DMUs), which receive multiple inputs and produce multiple outputs. DEA is a linear programming model that attempts to maximize a service unit's efficiency within the performance of a group of similar service units that are delivering the same service. Charnes et al. [3] introduced the generic term "decision making units" (DMU) to describe the collection of firms, departments, or divisions having multiple in commensurate input and output being assessed for efficiency. Since then it has been successfully used in many different sectors to assess and compare the efficiency of DMUs. CCR model which was built on the assumption of constant returns to scale (CRS) was also called global efficiency model [2]. Later, Banker et al. [1] introduced the BCC model based on variable returns to scale (VRS) and called the local efficiency model. DEA models are broadly divided into two categories on the basis of orientation. Input-oriented and output-oriented. Input-oriented models have the objective of minimizing inputs while maintaining the same level of outputs, whereas output-oriented models focus on increasing outputs with the same level of inputs. In this study an input-oriented (VRS) DEA model was used to determine efficient and inefficient DMUs.

\subsection{THE CCR EFFICIENCY MODEL}

It is also called technical efficiency model and the main assumption behind it is constant returns to scale, under which the production possibility set is formed without any scale effect. As Charnes et al. [3] reported the LP model deployed to generate the CCR efficiency factors of the DMUs considered is as follows.

The CCR model (to be solved for each $\mathrm{DMU}_{K 0}$ ).

$$
\operatorname{Max} \theta_{C C R}\left(k_{0}\right)=\sum_{j=0}^{n} U_{j} Y_{j k_{0}}
$$

Subject to: $\sum_{j=0}^{n} U_{j} Y_{j k_{0}}$

$$
\begin{gathered}
\sum_{i=0}^{m} \theta_{i} X_{i} k_{0}=1 \\
-\sum_{i=0}^{m} \theta_{i} X_{i} k_{0}+\sum_{i=0}^{m} U_{j} Y_{j k} \leq 0 \quad U_{j} \geq 0, \theta_{j} \geq 0
\end{gathered}
$$

$$
\begin{aligned}
k & =1, \ldots, k ; \\
j & =1, \ldots, n ; \\
i & =1, \ldots, m
\end{aligned}
$$

where, $U_{j}$ is the weight for output $j, \theta_{i}$ is the weight for input $i, m$ the number of inputs, $n$ the number of outputs, $K$ the number of $D M U_{S}, Y_{j k}$ the amount of output $j$ of $D M U_{K}$ and $x_{i k}$ the amount of input $I$ of $D M U_{K}$.

Table.1(a). Equivalents for various sources of energy and amount of input-output for energy equivalents of cowpea production

\begin{tabular}{|c|c|c|c|}
\hline Items & Unit & Equivalent MJ & Remarks \\
\hline Human Labour & Man-hour & 1.96 & \\
\hline Improved seeds & $\mathrm{Kg}$ & 15.2 & Processed \\
\hline Nitrogen & $\mathrm{Kg}$ & 60.60 & \\
\hline $\mathrm{P}_{2} \mathrm{O}_{5}$ & $\mathrm{Kg}$ & 11.1 & \\
\hline $\mathrm{K}_{2} \mathrm{O}$ & $\mathrm{Kg}$ & 6.7 & \\
\hline Herbicides & $\mathrm{Kg}$ & 238 & \\
\hline Insecticides & $\mathrm{Kg}$ & 101.2 & \\
\hline Manure & $\mathrm{Kg}$ & 18.0 & \\
\hline Cowpea product & $\mathrm{Kg}$ & 14.7 & \\
\hline Dry fodder & $\mathrm{Kg}$ & 18.0 & \\
\hline
\end{tabular}

Table.1(b). Amount of input-output and their energy equivalents for cowpea production

\begin{tabular}{|c|c|c|c|c|}
\hline Input & Qty ha & $\begin{array}{c}\text {-1 } \\
\text { Equivalent } \\
\text { MJ }\end{array}$ & $\begin{array}{c}\text { Total } \\
\text { energy } \\
\text { equivalent } \\
\text { MJha }^{-1} \text { ) }\end{array}$ & Percentage \\
\hline Human Labour & 326.587 & 1.96 & 640.11 & 1.99 \\
\hline $\begin{array}{c}\text { Improved } \\
\text { seeds }\end{array}$ & 4.244 & 15.2 & 64.51 & 0.20 \\
\hline Nitrogen & 25.6713 & 60.60 & 1555.68 & 4.83 \\
\hline $\mathrm{P}_{2} \mathrm{O}_{5}$ & 25.671 & 11.1 & 284.95 & 0.89 \\
\hline $\mathrm{K}_{2} \mathrm{O}$ & 25.67 & 6.7 & 172 & 0.53 \\
\hline Manure & 1613.754 & 238 & 29047.57 & 90.16 \\
\hline Herbicides & 1.352 & 101.2 & 321.80 & 1 \\
\hline Insecticides & 1.2594 & 18.0 & 127.45 & 0.40 \\
\hline Total input & & 14.7 & 8425.55 & 100 \\
\hline $\begin{array}{c}\text { Cowpea } \\
\text { product }\end{array}$ & 573.1667 & 18.0 & 26460 & \\
\hline Dry fodder & 1470 & & 34885.55 & \\
\hline $\begin{array}{c}\text { Total output } \\
\text { energy }\end{array}$ & & & 32214.07 & \\
\hline
\end{tabular}

\subsection{BCC EFFICIENCY MODEL}

It is called pure technical efficiency model, and the main assumption behind it is "variable returns to scale", under which the production possibility set is the convex combinations of the 
observed units. Banker, et al. [1] reported the LP model deployed to generate BCC efficiency factors of the DMUs is as follows. The BCC model (to be solved for each $D M U_{K 0}$ ).

$$
\operatorname{Max} \theta_{B C C}\left(k_{0}\right)=\sum_{j=0}^{n} U_{j} Y_{j k_{0}}-U\left(k_{0}\right)
$$

Subject to:

$$
\begin{gathered}
\sum_{i=0}^{m} \theta_{i} X_{i} k_{0}=1 \\
-\sum_{i=0}^{m} \theta_{i} X_{i} k_{0}+\sum_{i=0}^{m} U_{j} Y_{j k}-U\left(k_{0}\right) \leq 0 \quad U_{j} \geq 0, \theta_{j} \geq 0 \\
k=1, \ldots, k ; \\
j=1, \ldots, n ; \\
i=1, \ldots, m
\end{gathered}
$$

The inefficiency that a DMU might exhibit may have different causes, whether it is caused by the inefficient operation of the DMU itself or by the disadvantageous conditions, under which the DMU is operating, is an important issue to be clarified. In this regard, comparisons of the $\mathrm{CCR}$ and $\mathrm{BCC}$ efficiency scores deserve attention. The CCR model assumes a radial expansion and reduction of all observed DMUs (and their nonnegative combinations are possible), while the BCC model only accepts the convex combinations of the DMUs as the production possibility set. If a DMU is fully (100\%) efficient in both the CRR and BCC scores, it is operating at the most productive scale size. If a DMU has full BCC score, but a low CCR score, then it is locally efficient but not globally efficient due to its scale size. Thus, it is reasonable to characterize the scale efficiency of a DMU by the ratio of the two scores. So, scale efficiency is defined as,

$$
S E=\theta_{C C R} / \theta_{B C C}
$$

where, $\theta_{C C R}$ and $\theta_{B C C}$ are the CCR and BCC scores of a DMU, respectively. $S E=1$ shows scale efficiency (or CRS) and $S E<1$ indicates scale inefficiency. Scale inefficiency can be due to the existence of either increasing returns to scale (IRS) or decreasing returns to scale (DRS). But the shortcoming of the SE score is that it does not demonstrate if a DMU is operating under IRS or DRS. This is resolvable by simply imposing non-increasing returns to scale (NIRS) condition in the DEA model. IRS and DRS can be determined by comparing the efficiency scores obtained by the BCC and NIRS models, so, if the two efficiency scores are equal, then DRS apply, else IRS prevail. Energy saving target ratio (ESTR) helps to determine the inefficiency level of energy usage, index used is as follows,

$$
\operatorname{ESTR}(\%)=\frac{\text { Energy saving target }}{\text { Actual energy input }} \times 100 .
$$

ESTR represents each inefficiency level of energy consumption. The value of ESTR is between zero and unity. A higher ESTR implies higher energy use inefficiency, thus, a higher energy saving amount.

\subsection{GHG EMISSIONS}

$\mathrm{CO}_{2}$ emission coefficients of agricultural inputs were used to quantifying GHG emissions in cowpea production (Table.2).

\section{RESULTS AND DISCUSSION}

\subsection{MEASURING THE EFFICIENCY OF FARMERS}

Summarized statistics for the three estimated measures of efficiency indicated that the mean values of technical and pure technical efficiency scores were $0.86,0.90$ and 0.96 , respectively (Table.3). The technical efficiency varied from 0.38 to 1.00 range, the worst and best technical inefficient DMUs need to increase their efficiency scores by $62 \%$ and $0.3 \%$, respectively, to be on the frontier, while DMUs with average technical efficiency scores need to increase their efficiency scores by $16 \%$ to be on the frontier surface. The wide variation in the technical efficiency implies that majority of the farmers were not fully aware of the right production techniques or failed to apply them properly. The pure technical efficiency varied from 0.53 to 1.00 , the worst and best pure technical inefficient DMUs needs to decrease their inefficiency scores by $47 \%$ and $6 \%$, respectively, to be on the frontier surface, while the DMUs with mean pure technical efficiency scores need to decrease their inefficiency by $10 \%$ to be on the frontier. This wide variation implies that farmers were wasting resources due to poor allocation mix, thus justifying the fact that majority of the farmers failed to apply the right techniques either as a result of no awareness or poor resources base. The mean scale efficiency score was relatively low as 0.96 , indicating disadvantageous conditions of scale size. This means that if all the inefficient farmers operated at the most productive scale size, about $4 \%$ savings in energy use from different sources would be possible without affecting the yield level.

Table.2. GHG emission coefficients of agricultural inputs

\begin{tabular}{|c|c|c|}
\hline Items & Unit & $\begin{array}{c}\text { GHG coefficient } \\
\left(\mathbf{k g ~ C O} \text { eq. } \text { unit }^{-1} \text { ) }\right.\end{array}$ \\
\hline Nitrogen & $\mathrm{Kg}$ & 1.3 \\
\hline $\mathrm{P}_{2} \mathrm{O}_{5}$ & $\mathrm{Kg}$ & 0.2 \\
\hline $\mathrm{K}_{2} \mathrm{O}$ & $\mathrm{Kg}$ & 0.2 \\
\hline Herbicides & $\mathrm{Kg}$ & 6.3 \\
\hline Insecticides & $\mathrm{Kg}$ & 5.1 \\
\hline
\end{tabular}

However, distribution of the farmers based on the efficiency scores obtained by the application of CCR and BCC DEA models are shown in Fig. 1. As evident, about 35\% (14 farmers) and approximately $47.5 \%$ (19 farmers) from total farmers were recognized as the efficient farmers under constant and variable returns to scale assumptions, respectively. Among the efficient farmers, only 14 were fully efficient in both technical and pure technical efficiency scores, indicating that they were globally efficient and operated at the most productive scale size, however, the remaining 5 pure technically efficient farmers were only locally efficient, thus, attributed to their disadvantageous conditions of scale size. However, $42.5 \%$ and $35 \%$ have their technical and pure technical efficiency scores between 0.80 and 0.99 . However, when the BCC model was assumed, only $5 \%$ had an efficiency score of less than 0.60 , whereas, when the CCR model was applied, $10 \%$ had an efficiency score of less than 0.60 . 
Table.3. Deciles frequency distribution of efficiency scores

\begin{tabular}{|c|c|c|c|}
\hline Efficiency level & TE (\%) & PTE (\%) & SE (\%) \\
\hline$\leq 0.39$ & $1(2.5)$ & 0 & 0 \\
\hline $0.40-0.59$ & $3(7.5)$ & $2(5.0)$ & 0 \\
\hline $0.60-0.79$ & $5(12.5)$ & $5(12.5)$ & $2(5.0)$ \\
\hline $0.80-0.99$ & $17(42.5)$ & $14(35)$ & $23(57.5)$ \\
\hline 1.00 & $14(35)$ & $19(47.5)$ & $15(37.5)$ \\
\hline Total & 40 & 40 & 40 \\
\hline Minimum & 0.38 & 0.53 & 0.69 \\
\hline Maximum & 1.00 & 1.00 & 1.00 \\
\hline Mode & 1.00 & 1.00 & 1.00 \\
\hline Mean & 0.86 & 0.90 & 0.96 \\
\hline STD & 0.177 & 0.146 & 0.084 \\
\hline
\end{tabular}

( ). percentage

Source: Computed from DEAP 2.1 computer print-out



Fig.1. Efficiency score distribution of cowpea producers

\subsection{RETURN TO SCALE PROPERTIES}

The information on whether a farmer operates at IRS, CRS or DRS is particularly helpful in indicating the potential redistribution of resources between the farmers, thus, enable them to achieve higher yield value. The analysis shows that DMUs numbered $1,2,3,14,15,16,24,29,30,33,37,38,39,40$ that are efficient under the CRS model are both technically and scale efficient (Table.4). The RTS indicated that all efficient farms (based on scale efficiency) were operating at CRS and for inefficient farms technological change is required for considerable changes in output. In summary, a total of 15 DMUs, 18 DMUs and 7 DMUs were operating at CRS, IRS and DRS, respectively. Therefore, since majority of the farmers are in stage I, proportionate increase in all inputs leads to more proportionate increase in output, and for considerable changes in yield, technological changes in practices need to be put in place.
Table.4. Characteristics of farms with respect to return to scale

\begin{tabular}{|c|c|c|}
\hline Scale & No. of farms & Mean energy output \\
\hline Sub-optimal & 18 & 6996.11 \\
\hline Optimal & 15 & 9747.73 \\
\hline Super-optimal & 7 & 9268 \\
\hline \multicolumn{3}{|c|}{ Source: Computed from DEAP 2.1 computer print-out }
\end{tabular}

\subsection{RANKING THE EFFICIENT FARMERS}

Identifying efficient operating practices and their dissemination will help to improve efficiency not only in the case of inefficient farmers but also for relatively efficient ones, because efficient farmers obviously follow good operational practices. However, among the efficient farmers, some show better operational practices than others, therefore, discrimination need to be made among the efficient farmers while seeking the best operational practices. In order to have the efficient farmers ranked, the number of time an efficient DMU appeared in a referent set was counted, and results obtained from the analysis showed that DMUs 1-2, 3-6, 14-21, 24-29, 32-33, 37-38, and 3940 appeared $10-2,4-6,3-1,13-3,9-2,6-3$ and $9-8$ times in the referent set, respectively (Table.5), with farm 24 having the highest appearance in the referent set. The farm 24 appears thirteen times in the reference set of inefficient DMUs, thus, placing farm 24 closest to the input and output levels of most of the inefficient DMUs, but uses less inputs. However, these efficient farms can be selected by inefficient DMUs as best practice DMUs, making them a composite DMU instead of using a single DMU as a benchmark. While the referent set is composed of the efficient units which are similar to the input and output levels of inefficient units, efficient DMUs with more appearance in referent set are known as superior unit in the ranking. Results of this analysis would be beneficial to inefficient farmers to manage their energy sources usage in order to attain best performance in energy use efficiency.

Table.5. Benchmarking of efficient DMUs

\begin{tabular}{|c|c|c|c|c|c|}
\hline $\begin{array}{c}\text { DMU } \\
\text { (farm) }\end{array}$ & $\begin{array}{c}\text { Frequency } \\
\text { in referent } \\
\text { set }\end{array}$ & Ranking & $\begin{array}{c}\text { DMU } \\
\text { (farm) }\end{array}$ & $\begin{array}{c}\text { Frequency } \\
\text { in referent } \\
\text { set }\end{array}$ & Ranking \\
\hline DMU24 & 13 & 1 & DMU03 & 4 & 6 \\
\hline DMU01 & 10 & 2 & DMU14 & 3 & 7 \\
\hline DMU32 & 9 & 3 & DMU29 & 3 & 7 \\
\hline DMU39 & 9 & 3 & DMU38 & 3 & 7 \\
\hline DMU40 & 8 & 4 & DMU02 & 2 & 8 \\
\hline DMU06 & 6 & 5 & DMU33 & 2 & 8 \\
\hline DMU37 & 6 & 5 & DMU21 & 1 & 9 \\
\hline
\end{tabular}

\subsection{PERFORMANCE ASSESSMENT}

The performance assessment may be carried out by comparing a particular system with key competitors having best performance within the same group or another group performing similar functions, a process called benchmarking [4] [7] [18] and [20]. 
Efficient DMUs can be selected by inefficient DMUs as best practice DMUs, making them a composite DMU instead of using a single DMU as a benchmark. A composite DMU is formed by multiplying the intensity vector $\lambda$ in the inputs and outputs of the respective efficient DMUs. BCC is modeled by setting the convexity constraint, and summation of all intensity vectors in a benchmark DMU must be equal to 1 [10]. The perusal of Table. 6 showed the worst inefficient DMUs (DMU8 and DMU13) and the best inefficient DMUs (DMU36 and DMU34). For example, in the case of DMU8 the composite DMU that represents the best practice or reference composite benchmark DMU is formed by the combination of DMU6, DMU1 and DMU32, meaning DMU8 is close to the efficient frontier segment formed by these efficient DMUs represented in the composite DMU. The selections of these efficient DMUs are made on the basis of their comparable level of inputs and output yield to DMU8. However, the benchmark DMUs for DMU8 are expressed as 6(0.068) 1(0.360) and 32(0.572), where 6, 1 and 32 are the DMU numbers while the values between brackets are the intensity vector $\lambda$ for the respective DMUs. The higher value of the intensity vector $\lambda$ for DMU6 (0.356) indicates that its level of inputs and output is closer to DMU8 compared to the other DMUs in the reference set or composite DMU.

Table.6. Performance assessment of farms

\begin{tabular}{|c|c|c|}
\hline DMU (Farm) & PTE score (\%) & Benchmarks \\
\hline DMU8 & 53.2 & $6(0.068) 1(0.360) 32(0.572)$ \\
\hline DMU13 & 53.3 & $\begin{array}{c}6(0.356) 1(0.029) 24(0.278) \\
40(0.336)\end{array}$ \\
\hline DMU36 & 91.9 & $\begin{array}{c}24(0.036) 1(0.255) 40(0.192) \\
39(0.517) 32(0.001)\end{array}$ \\
\hline DMU34 & 93.8 & $\begin{array}{c}39(0.131) 33(0.487) 3(0.128) \\
24(0.255)\end{array}$ \\
\hline
\end{tabular}

Source: Computed from DEAP 2.1 computer print-out

\subsection{SETTING REALISTIC INPUT LEVELS FOR INEFFICIENT FARMERS}

A pure technical efficiency score of less than one for a farmer indicates that, at present conditions, he is using higher values of energy than required. Therefore, it is desired to suggest realistic levels of energy to be used from each source for every inefficient farmer in order to avert wastage of energy. The summarized information for setting realistic input levels are presented in Table.7. It gives the average energy usage in actual and optimum conditions $\left(\mathrm{MJha}^{-1}\right)$, possible energy savings and ESTR percentage for different energy sources. It is evident that, total energy input could be reduced to $23075.11 \mathrm{MJha}^{-1}$, while, maintaining the current production level and also assuming no other constraining factors. Energy requirements from Manure, NPK fertilizer, human labour and herbicides were 20608.15 $\mathrm{MJha}^{-1}$, $1535.86 \mathrm{MJha}^{-1}$, $550.07 \mathrm{MJha}^{-1}$ and $228.07 \mathrm{MJha}^{-1}$, respectively. However, the quantity of energy inputs required from insecticides and seeds were 99.05 $\mathrm{MJha}^{-1}$ and $53.91 \mathrm{MJha}^{-1}$, respectively.

The results of ESTR showed that if all farmers operated efficiently, reductions in herbicides, manure, NPK fertilizer and insecticides energy inputs, with respect, by $29.13 \%, 29.05 \%$, $23.63 \%$ and $22.28 \%$ would have been possible without affecting the present productivity level. These energy inputs had the highest inefficiency which owed mainly to excess use. High percentages of NPK fertilizer and manure energy inputs can be attributed to low prices and free availability of these inputs, respectively, in the study area. Accurate fertilizer management by increasing its profitability with the crops and reducing losses by improving management practices can improve energy use. On the other hand, the ESTR for seeds and human labour energy inputs were found to be $16.43 \%$ and $14.07 \%$, respectively, indicating that these inputs were fairly used efficiently by the farmers in the study area. Moreover, results revealed that, the ESTR percentage for total energy input was $28.37 \%$, indicating that by adopting the recommendations resulted from this study, on the average, approximately $28.37 \%\left(9138.96 \mathrm{MJha}^{-1}\right)$ from total input energy in cowpea production could be saved without affecting the yield level. In related studies, Sadiq, et al. [15] reported that $38.17 \%$ $\left(1505.58 \mathrm{MJha}^{-1}\right)$ of the overall inputs in sesame production in Jigawa State of Nigeria could be saved without affecting the yield level. Also, Avval, et al. [8] found that $20 \%$ of overall resources in soybean production could be reduced if all of the farmers operate efficiently and the yield level will not be affected. Using this information, it is possible to advise the inefficient farmers regarding better operating practices followed by the peers in order to reduce the input energy levels to the optimum values indicated in the analysis while maintaining the current output level achieved by them.

Further perusal of Table.7 shows saving energy from different sources for cowpea production, and it is evident that the maximum contribution to the total saving energy is $92.35 \%$ from manure fertilizer. Also, NPK fertilizer and biocides energy inputs contributed to the total saving energy by approximately $6.55 \%$. From these results it is strongly suggested that improving the usage pattern of these inputs be considered as priorities in providing significant improvement in energy productivity for cowpea production in the study area. Adopting better management techniques, adopting conservation tillage methods, cultural and biological practices, and controlling input usage by performance monitoring can aid in reducing inorganic fertilizer and biocides energy inputs, thereby minimizing their environmental footprints. Also, application of composts, chopped residues or other soil amendments may increases soil fertility in the medium term, thereby reduce the need for chemical fertilizer energy input.

Table.7. Energy saving $\left(\mathrm{MJha}^{-1}\right)$ from different sources if recommendations of study are followed

\begin{tabular}{|c|c|c|c|c|}
\hline Input & $\begin{array}{c}\text { Actual } \\
\text { energy } \\
\text { used } \\
\left(\mathbf{M J h a}^{-1}\right)\end{array}$ & $\begin{array}{c}\text { Optimum } \\
\text { energy } \\
\text { requirement }_{\left(\mathbf{M J h a}^{-1}\right)}\end{array}$ & Energy saving & $\begin{array}{c}\text { ESTR } \\
(\boldsymbol{\%})\end{array}$ \\
\hline $\begin{array}{c}\text { Human } \\
\text { Labour }\end{array}$ & 640.11 & 550.07 & $90.04(0.98)$ & 14.07 \\
\hline Seed & 64.11 & 53.91 & $10.06(0.12)$ & 16.43 \\
\hline Nitrogen & 1555.68 & 1186.59 & $369.09(4.04)$ & 23.73 \\
\hline $\mathrm{P}_{2} \mathrm{O}_{5}$ & 284.95 & 217.80 & $67.15(0.73)$ & 23.57 \\
\hline $\mathrm{K}_{2} \mathrm{O}$ & 172 & 131.47 & $40.53(0.44)$ & 23.57 \\
\hline Manure & 29047.57 & 20608.15 & $8439.42(92.35)$ & 29.05 \\
\hline
\end{tabular}




\begin{tabular}{|c|c|c|c|c|}
\hline Herbicides & 321.80 & 228.07 & $93.73(1.03)$ & 29.13 \\
\hline Insecticides & 127.45 & 99.05 & $28.4(0.31)$ & 22.28 \\
\hline $\begin{array}{c}\text { Total } \\
\text { energy } \\
\text { input }\end{array}$ & 32214.07 & 23075.11 & $9138.96(100)$ & 28.37 \\
\hline
\end{tabular}

( ). percentage

Source: Computed from DEAP 2.1 computer print-out

\subsection{ENERGY INDICES IMPROVEMENT}

The energy indices for cowpea production in actual and optimum use of energy are presented in Table.8. Making a comparison between energy indices in actual energy use and target energy use showed improvements of these indices. The estimated energy ratio of cowpea production in the studied area was 1.08 and can be improved to the value of 1.51 . Energy productivity, specific energy and net energy were observed to be $0.063 \mathrm{KgMJ}^{-1}$, $15.77 \mathrm{MJKg}^{-1}$ and $2671.48 \mathrm{MJha}^{-1}$, respectively, and they can be enhanced to the values of $0.089 \mathrm{KgMJ}^{-1}, 11.29 \mathrm{MJKg}^{-1}$ and $11810.44 \mathrm{MJha}^{-1}$. It is evident that by optimization of energy use, both the energy ratio and energy productivity indicators can improve by approximately $39.82 \%$ and $41.27 \%$, respectively. Also, in optimum consumption of energy inputs, the net energy indicator by improvement of $342.1 \%$ would increase to $11810.44 \mathrm{MJha}^{-1}$.

Table.8. Comparison between energy indices and improved energy indices for Cowpea Production

\begin{tabular}{|c|c|c|c|c|}
\hline Items & Unit & $\begin{array}{c}\text { Qty in } \\
\text { Actual use } \\
(\mathbf{A})\end{array}$ & $\begin{array}{c}\text { Qty in } \\
\text { optimum } \\
\text { use (B) }\end{array}$ & $\begin{array}{c}\text { Difference } \\
(\mathbf{\%})\{(\mathbf{B}- \\
\mathbf{A} / \mathbf{A})\}^{* 100}\end{array}$ \\
\hline Energy ratio & - & 1.08 & 1.51 & 39.82 \\
\hline $\begin{array}{c}\text { Energy } \\
\text { productivity }\end{array}$ & $\begin{array}{c}\mathrm{KgMJ}^{-} \\
1\end{array}$ & 0.063 & 0.089 & 41.27 \\
\hline $\begin{array}{c}\text { Specific } \\
\text { energy }\end{array}$ & $\begin{array}{c}\mathrm{MJKg}^{-} \\
1\end{array}$ & 15.77 & 11.29 & -28.41 \\
\hline Net energy & $\mathrm{MJha}^{-1}$ & 2671.48 & 11810.44 & 342.1 \\
\hline $\begin{array}{c}\text { Direct energy } \\
\mathrm{MJha}^{-1}\end{array}$ & 640.11 & 550.07 & -28.66 \\
\hline $\begin{array}{c}\text { Indirect } \\
\text { energy }\end{array}$ & $\mathrm{MJha}^{-1}$ & 31573.96 & 22525.04 & -28.70 \\
\hline $\begin{array}{c}\text { Renewable } \\
\text { energy }\end{array}$ & $\mathrm{MJha}^{-1}$ & 29752.19 & 21212.13 & -24.33 \\
\hline $\begin{array}{c}\text { Non- } \\
\text { renewable } \\
\text { energy }\end{array}$ & $\mathrm{MJha}^{-1}$ & 2461.88 & 1862.98 & 5.63 \\
\hline $\begin{array}{c}\text { Agro- } \\
\text { chemical }\end{array}$ & $\%$ & 7.64 & 8.07 & 5.63 \\
\hline $\begin{array}{c}\text { Total input } \\
\text { energy }\end{array}$ & $\mathrm{MJha}^{-1}$ & 32214.07 & 23075.11 & -28.37 \\
\hline
\end{tabular}

Source: Computed from DEAP 2.1 computer print-out

\subsection{REDUCTION OF GHG EMISSION}

GHG emissions of actual and optimum units were investigated to determine the role of energy optimization in environmental condition of cowpea production in the studied area (Table.9). The total GHG emissions of actual and optimum units were calculated as $58.57 \mathrm{KgCO}_{2 \mathrm{eq}} \mathrm{ha}^{-1}$ and $44.34 \mathrm{KgCO}_{2 \mathrm{eq}} \mathrm{ha}^{-1}$, respectively. Accordingly, the total GHG emissions can be reduced by $14.23 \mathrm{KgCO}_{2 \mathrm{eq}} \mathrm{ha}^{-1}$ using DEA energy optimization techniques, the optimum GHG emission by $24.30 \%$ decrease can be reduced to the value of $44.34 \mathrm{KgCO}_{2 \mathrm{eq}} \mathrm{ha}^{-1}$. Furthermore, most amount of $\mathrm{CO}_{2}$ emission was related to nitrogen fertilizers with approximate value of $7.92 \mathrm{KgCO}_{2 \mathrm{eq}}$, and then followed by herbicides. Therefore, it can be inferred that energy consumption had a direct relationship with GHG emissions, and subsequently, the energy consumption can be reduced by improving some agricultural practices and technological changes in inefficient DMUs.

Table.9. Amount of GHG emission for actual and optimum

\begin{tabular}{|c|c|c|c|}
\hline Input & $\begin{array}{c}\text { Actual } \\
\left(\mathbf{K g C O}_{2} \mathbf{h a}^{-1}\right) \\
(\mathbf{A})\end{array}$ & $\begin{array}{c}\text { Optimum } \\
\left(\mathbf{K g C O}_{2} \mathbf{h a}^{-1}\right) \\
(\mathbf{B})\end{array}$ & $\begin{array}{c}\text { GHG reduction } \\
\left.\text { KgCO }_{2} \mathbf{h a}^{-1}\right)\end{array}$ \\
\hline Nitrogen & 33.37 & 25.45 & $7.92(55.66)$ \\
\hline $\mathrm{P}_{2} \mathrm{O}_{5}$ & 5.13 & 3.92 & $1.21(8.50)$ \\
\hline $\mathrm{K}_{2} \mathrm{O}$ & 5.13 & 3.92 & $1.21(8.50)$ \\
\hline Herbicides & 8.52 & 6.05 & $2.47(17.36)$ \\
\hline Insecticides & 6.42 & 4.998 & $1.42(9.98)$ \\
\hline Total & 58.57 & 44.34 & $14.23(100)$ \\
\hline
\end{tabular}

Source: Computed from DEAP 2.1 computer print-out

The Fig.2 displays the share of each input in total GHG reduction in cowpea production with nitrogen fertilizers $(55.66 \%)$ having the highest share in GHG emission reduction, followed by herbicides $(17.36 \%)$, insecticides $(9.98 \%)$, and $\mathrm{P}_{2} \mathrm{O}_{5}$ and $\mathrm{K}_{2} \mathrm{O}$ fertilizers $(8.50 \%$ in both cases). Using renewable sources of energy in improving fertility of the soil and replacing biocides with cultural practices can lead to cultivation with less GHG.

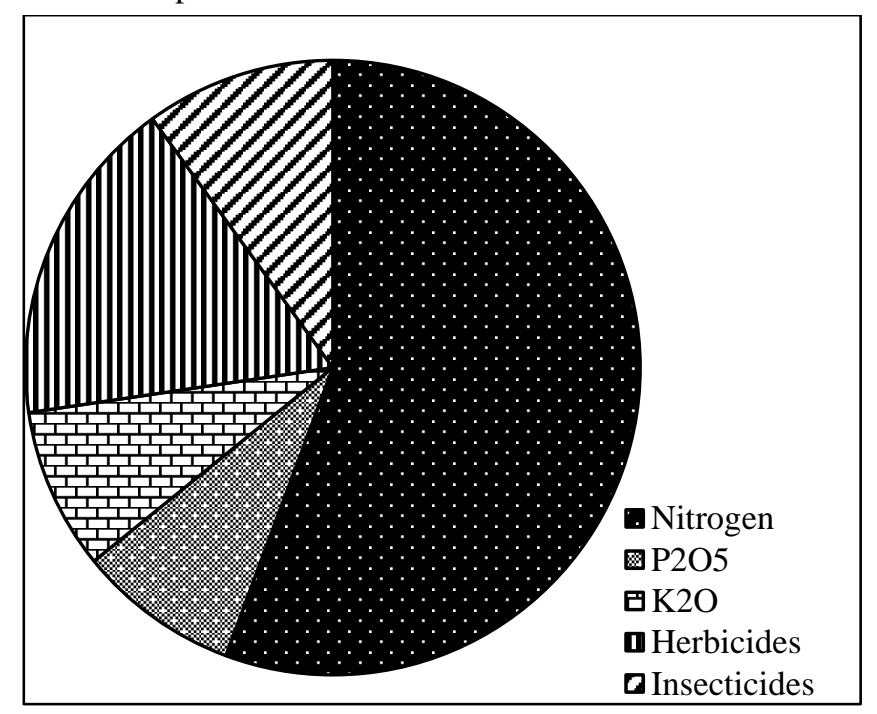

Fig.2. Share of each input for GHG emission reduction

\section{CONCLUSION AND RECOMMENDATIONS}

Pathways to improve energy efficiency and minimize the environmental footprints of GHG emission of energy inputs used in cowpea production in Niger state of Nigeria was investigated 
using data envelopment analysis. This technique helped to measure efficiency scores of farmers, segregate efficient farmers from inefficient farmers, find the wasteful uses of energy by inefficient farmers and the effect of energy optimization on greenhouse gas $(\mathrm{GHG})$ emission. Findings indicated that there are substantial production inefficiencies for farmers, so that, a potential of approximately $28.37 \%$ reduction in total energy input used may be achieved if all farmers operated efficiently and assuming no other constraints on this adjustment. Based on results it was observed that total GHG emission in actual unit was $58.57 \mathrm{KgCO}_{2 \mathrm{eq}} \mathrm{ha}^{-1}$ and can be reduced $44.34 \mathrm{KgCO}_{2 \mathrm{eq}} \mathrm{ha}^{-1}$ if inefficient farmers adopt the recommendations resulted from this study. Moreover, results revealed that cowpea production in the studied area showed a high sensitivity on non-renewable energy sources which may result in environmental deterioration and rapid rate of depletion of these energetic resources. Therefore, policies should emphasize on development of new technologies to substitute agrochemical with renewable energy sources aimed towards efficient energy use and lowering the environmental footprints of GHG emissions. Furthermore, development of renewable energy usage technologies, applying better management techniques, adopting conservation tillage methods, utilization of alternative sources of energy such as organic fertilizers may be suggested to reduce the environmental footprints of GHG emission from energy inputs and to obtain sustainable food production systems.

\section{REFERENCES}

[1] R.D. Banker, A. Charnes and W.W. Cooper, "Some Models for Estimating Technical and Scale Inefficiencies in Data Envelopment Analysis", Management Science, Vol. 30, No. 9, pp. 1078-1092, 1984.

[2] A. Charnes and W.W. Cooper, "The Non-Archimedean CCR Ratio for Efficiency Analysis: A Rejoinder to Boyd and Fare", European Journal of Operational Research, Vol. 15, No. 3, pp. 333-334, 1984.

[3] A.W. Charnes, W. Copper and E. Rhodes, "Measuring the Efficiency of Decision Marking Units", European Journal of Operational Research, Vol. 2, No. 1, pp. 429-444, 1978.

[4] R. Fadavi, A. Keyhani and S.S. Mohtasebi, "An Analysis of Improving Energy use with Data Envelopment Analysis in Apple Orchard", Global Advanced Research Journal of Agricultural Science, Vol. 1, No. 4, pp. 81-89, 2012.

[5] B. Khoshnevisan, S. Rafiee, M. Omid and H. Mousazadeh, "Applying Data Envelopment Analysis Approach to Improve Energy Efficiency and Reduce GHG (Greenhouse Gas) Emission of Wheat Production", Energy, Vol. 58, pp. 588-593, 2013.

[6] B. Khoshnevisan, S. Rafiee, M. Omid, M. Yousefi and M. Movahedi, "Modeling of Energy Consumption and GHG (Greenhouse Gas) Emissions in Wheat Production in Esfahan Province of Iran using Artificial Neural Networks", Energy, Vol. 52, pp. 333-338, 2013.

[7] Marcia Carvalho, Teresa Lino-Neto, Eduardo Rosa and Valdemar Carnide, "Cowpea: A Legume Crop for a Challenging Environment", Journal of the Science of Food and Agriculture, Vol. 97, No. 13, pp. 4273-4284, 2017.

[8] S.H. Mousavi-Avval, S. Rafiee, A. Jafari and A. Mohammadi, "Optimization of Energy Consumption for
Soybean Production using Data Envelopment Analysis (DEA) Approach", Applied Energy, Vol. 88, No. 11, pp. 3765-3772.

[9] A. Nabavi-Pelesaraei, R. Abdi, S. Rafiee and H. GhasemiMobtaker, "Optimization of Energy Required and Greenhouse Gas Emissions Analysis for Orange Producers using Data Envelopment Analysis Approach", Journal of Cleaner Production, Vol. 65, pp. 311-317.

[10] M. Omid, F. Ghojabeige, M. Delshad and H. Ahmadi, "Energy use Pattern and Benchmarking of Selected Greenhouses in Iran using Data Envelopment Analysis", Energy Conversion and Management, Vol. 52, No. 1, pp. 153-162, 2010.

[11] E.G. Onuk, E.S. Salau and A. Sale, "Economics of MaizeCowpea Intercropped Production in Kokona Local Government Area of Nasarawa State, Nigeria", World Academic Journal of Agriculture and Global Food Security, Vol. 2, No. 3, pp. 200-205, 2017.

[12] S.H. Pishgar-Komleh, M. Ghahderijani and P. Sefeedpari, "Energy Consumption and $\mathrm{CO}_{2}$ Emissions Analysis of Potato Production based on Different Farm Size Levels in Iran”, Journal of Cleaner Production, Vol. 33, pp. 183-191, 2012.

[13] S.H. Pishgar-Komleh, M. Omid and M.D. Heidari, "On the Study of Energy use and GHG (Greenhouse Gas) Emissions in Greenhouse Cucumber Production in Yazd Province", Energy, Vol. 59, pp. 63-71, 2013.

[14] P. Qasemi-Kordkheili and A. Nabavi-Pelesaraei, "Optimization of Energy Required and Potential of Greenhouse Gas Emissions Reductions for Nectarine Production using Data Envelopment Analysis Approach". International Journal of Energy and Environment, Vol. 5, No. 2, pp. 207-218, 2014.

[15] M.S. Sadiq, I.P. Singh, S.A. Makama, S.M. Umar, M.A. Isah and I.J. Grema, "Agrarian Crisis and Steps to Combat it: Evidence of GHG Emission $\left(\mathrm{CO}_{2}\right)$ in Sesame Production in Jigawa State, Nigeria", Indian Journal of Economics and Development, Vol. 12, No. 2, pp. 73-80, 2016.

[16] M.S. Sadiq, I.P. Singh, A. Suleiman, M.A. Isah, M.A., S.M. Umar, A.M. Maude, A.T. Lawal and H. Sallawu, "Application of Data Envelopment Analysis (DEA) in Determining GHG Emission and Carbon Sequestration in Small-Scale Maize Production in Niger State, Nigeria", Agricultural and Bio-Nutritional Research, Vol. 1, No. 1, pp. 1-19, 2015.

[17] M.S. Sadiq, I.P. Singh, S.M. Umar, I.J. Grema, B.I. Usman and M.A. Isah, "Identifying Sustainable and Efficient Broiler Farms in the Light of Energy use Efficiency and GHG Emission Reduction: Data Envelopment Analysis", Proceedings of $4^{\text {th }}$ Interdisciplinary International Conference, pp. 24-28, 2016.

[18] D.V. Singh and S.K. Mukhi, "Phasic Pattern of Dry Matter Production and Accumulation in Different Parts of Cowpea Cultivars during Growth and Development Stages under Varied Seasons", International Journal of Current Microbiology and Applied Sciences, Vol. 6, No. 4, pp. 347355, 2017.

[19] P. Soni, C. Taewichit and V. Salokhe, "Energy Consumption and $\mathrm{CO}_{2}$ Emissions in Rain Fed Agricultural Production 
Systems of Northeast Thailand", Agricultural Systems, Vol. 116, No. 1, pp. 25-36, 2013.

[20] Stephen Kyei-Boahen, Canon E.N. Savala, David Chikoye and Robert Abaidoo, "Growth and Yield Responses of
Cowpea to Inoculation and Phosphorus Fertilization in Different Environments", Frontiers in Plant Science, Vol. 8, No. 646, pp. 414-482, 2017.

\section{APPENDIX I}

The source wise actual and optimum energy use for inefficient farmers in cowpea production (BCC model based)

\begin{tabular}{|c|c|c|c|c|c|c|c|c|c|}
\hline \multirow{2}{*}{ DMU } & \multirow{2}{*}{ PTE } & \multicolumn{8}{|c|}{ Actual energy use (MJha $\left.{ }^{-1}\right)$} \\
\hline & & Seeds & Nitrogen & $\mathbf{P}_{\mathbf{2}} \mathbf{O}_{5}$ & $\mathbf{K}_{\mathbf{2}} \mathbf{O}$ & Manure & Labour & Herbicides & Insecticides \\
\hline 4 & 0.879 & 45.60 & 999.90 & 183.15 & 110.55 & 45900 & 556.64 & 238.00 & 202.40 \\
\hline 5 & 0.897 & 101.33 & 3999.60 & 732.60 & 442.20 & 24480 & 682.08 & 317.33 & 134.93 \\
\hline 7 & 0.867 & 81.07 & 666.60 & 122.10 & 73.70 & 21600 & 585.39 & 317.33 & 134.93 \\
\hline 8 & 0.532 & 91.20 & 1599.84 & 293.04 & 176.88 & 12240 & 627.20 & 317.33 & 134.93 \\
\hline 9 & 0.637 & 76.00 & 999.90 & 183.15 & 110.55 & 27540 & 635.04 & 476.00 & 202.40 \\
\hline 10 & 0.716 & 45.60 & 999.90 & 183.15 & 110.55 & 32400 & 588.00 & 476.00 & 202.40 \\
\hline 11 & 0.884 & 81.07 & 666.60 & 122.10 & 73.70 & 9180 & 689.92 & 793.33 & 134.93 \\
\hline 12 & 0.611 & 91.2 & 999.90 & 183.15 & 110.55 & 32400 & 705.60 & 476.00 & 101.20 \\
\hline 13 & 0.535 & 70.93 & 1599.84 & 293.04 & 176.88 & 45900 & 642.88 & 317.33 & 134.93 \\
\hline 17 & 0.848 & 76.00 & 2999.70 & 549.45 & 331.65 & 16299 & 588.00 & 238.00 & 151.80 \\
\hline 19 & 0.917 & 83.60 & 1999.80 & 366.30 & 221.10 & 22950 & 666.40 & 357.00 & 50.60 \\
\hline 20 & 0.876 & 76.00 & 2999.70 & 549.45 & 331.65 & 22950 & 1015.28 & 476.00 & 202.40 \\
\hline 22 & 0.917 & 76.00 & 999.90 & 183.15 & 110.55 & 12240 & 572.32 & 158.67 & 67.47 \\
\hline 25 & 0.729 & 60.80 & 1999.80 & 366.30 & 221.10 & 28960 & 642.88 & 158.67 & 134.93 \\
\hline 26 & 0.701 & 91.20 & 1999.80 & 366.30 & 221.10 & 10160 & 776.16 & 476.00 & 101.20 \\
\hline 27 & 0.874 & 50.67 & 1999.70 & 366.30 & 221.10 & 21200 & 653.33 & 158.67 & 67.47 \\
\hline 28 & 0.821 & 76.00 & 2999.90 & 549.45 & 331.65 & 25900 & 619.36 & 476.00 & 202.40 \\
\hline 31 & 0.809 & 60.80 & 2999.80 & 549.45 & 331.65 & 32598 & 932.96 & 476.00 & 202.40 \\
\hline 34 & 0.938 & 45.60 & 999.80 & 183.15 & 110.55 & 25900 & 748.72 & 476.00 & 202.40 \\
\hline 35 & 0.902 & 53.20 & 2399.76 & 439.56 & 265.32 & 26720 & 768.32 & 476.00 & 202.40 \\
\hline 36 & 0.919 & 76.00 & 1499.85 & 274.73 & 165.83 & 16299 & 611.52 & 238.00 & 101.20 \\
\hline Average & 0.800 & 1829.98 & 335.19 & 335.19 & 202.32 & 24467.43 & 681.33 & 375.89 & 146.18 \\
\hline STD & 0.127 & 917.46 & 168.05 & 168.05 & 101.44 & 9865.40 & 113.06 & 150.73 & 50.56 \\
\hline
\end{tabular}

\begin{tabular}{|c|c|c|c|c|c|c|c|c|}
\hline \multicolumn{7}{|c|}{ Optimum energy requirement $\left(\mathbf{M J h a}^{-1}\right)$} & \multirow{2}{*}{ ESTR (\%) } \\
\cline { 1 - 9 } Seeds & Nitrogen & $\mathbf{P}_{\mathbf{2}} \mathbf{O}_{\mathbf{5}}$ & $\mathbf{K}_{\mathbf{2}} \mathbf{O}$ & Manure & Labour & Herbicides & Insecticides & \\
\hline 40.07 & 878.70 & 160.95 & 97.15 & 21845.40 & 382.97 & 209.15 & 116.53 & 50.80 \\
\hline 76.00 & 1666.50 & 305.25 & 184.25 & 16830.02 & 611.52 & 158.67 & 67.47 & 35.58 \\
\hline 45.98 & 577.83 & 105.84 & 63.89 & 18723.46 & 409.71 & 275.07 & 85.44 & 13.97 \\
\hline 37.09 & 739.98 & 135.54 & 81.81 & 6506.80 & 333.42 & 168.70 & 71.73 & 47.84 \\
\hline 47.41 & 637.40 & 116.75 & 70.47 & 17555.64 & 404.81 & 239.48 & 80.74 & 36.63 \\
\hline 32.64 & 715.77 & 131.12 & 79.14 & 22345.32 & 420.92 & 260.13 & 140.47 & 31.08 \\
\hline 25.76 & 589.26 & 107.93 & 65.15 & 8114.87 & 274.17 & 226.21 & 96.19 & 19.10 \\
\hline
\end{tabular}




\begin{tabular}{|l|c|c|c|c|c|c|c|c|}
\hline 50.26 & 611.14 & 111.94 & 67.57 & 19803.05 & 431.27 & 218.17 & 61.85 & 39.10 \\
\hline 37.44 & 855.90 & 156.77 & 94.63 & 17530.50 & 343.93 & 136.68 & 72.19 & 60.87 \\
\hline 64.48 & 1264.53 & 231.62 & 139.81 & 13828.05 & 498.86 & 177.15 & 75.33 & 23.33 \\
\hline 76.00 & 1433.37 & 280.86 & 169.53 & 11123.50 & 611.39 & 109.18 & 46.42 & 48.12 \\
\hline 66.59 & 1619.00 & 296.55 & 179.00 & 20108.05 & 702.34 & 238.00 & 125.32 & 18.41 \\
\hline 61.58 & 916.93 & 167.95 & 101.38 & 11224.32 & 508.81 & 145.50 & 61.87 & 8.47 \\
\hline 44.32 & 1256.72 & 230.19 & 138.94 & 19716.57 & 468.65 & 115.67 & 62.04 & 32.30 \\
\hline 63.89 & 1400.91 & 256.60 & 154.89 & 11002.05 & 543.72 & 145.49 & 70.89 & 3.90 \\
\hline 44.26 & 1655.86 & 303.30 & 183.07 & 20955.61 & 570.75 & 134.37 & 58.94 & 3.28 \\
\hline 62.39 & 1327.06 & 243.08 & 146.72 & 20196.89 & 508.47 & 217.44 & 101.20 & 26.81 \\
\hline 49.20 & 1518.40 & 278.12 & 167.88 & 26378.27 & 754.95 & 215.22 & 160.94 & 22.62 \\
\hline 42.77 & 937.83 & 171.78 & 103.69 & 26175.96 & 702.24 & 353.81 & 163.35 & 0.05 \\
\hline 47.98 & 1684.23 & 308.50 & 186.21 & 27114.82 & 692.89 & 207.35 & 130.93 & 3.04 \\
\hline 69.85 & 1378.45 & 252.49 & 152.40 & 14979.74 & 562.02 & 193.37 & 84.03 & 8.27 \\
\hline 51.71 & 1126.94 & 207.29 & 125.12 & 17717.09 & 511.32 & 197.37 & 92.09 & 28.75 \\
\hline 13.98 & 391.27 & 72.45 & 43.73 & 5678.39 & 131.49 & 57.87 & 33.64 & 17.37 \\
\hline
\end{tabular}

\section{APPENDIX II}

Technical, Scale Efficiencies and Returns to Scale

\begin{tabular}{|c|c|c|c|c|c|c|c|c|c|c|c|}
\hline DMU & TE & PTE & NIRS & SE & RS & DMU & TE & PTE & NIRS & SE & RS \\
\hline 1 & 1.000 & 1.000 & 1.000 & 1.000 & CRS & 21 & 0.957 & 1.000 & 0.957 & 0.957 & IRS \\
\hline 2 & 1.000 & 1.000 & 1.000 & 1.000 & CRS & 22 & 0.866 & 0.917 & 0.866 & 0.944 & IRS \\
\hline 3 & 1.000 & 1.000 & 1.000 & 1.000 & CRS & 23 & 0.977 & 1.000 & 0.977 & 0.977 & DRS \\
\hline 4 & 0.873 & 0.879 & 0.873 & 0.993 & DRS & 24 & 1.000 & 1.000 & 1.000 & 1.000 & CRS \\
\hline 5 & 0.839 & 0.879 & 0.839 & 0.936 & DRS & 25 & 0.713 & 0.729 & 0.713 & 0.978 & IRS \\
\hline 6 & 0.829 & 1.000 & 0.829 & 0.826 & IRS & 26 & 0.692 & 0.701 & 0.692 & 0.988 & IRS \\
\hline 7 & 0.712 & 0.867 & 0.712 & 0.821 & IRS & 27 & 0.846 & 0.874 & 0.846 & 0.969 & IRS \\
\hline 8 & 0.382 & 0.532 & 0.382 & 0.718 & IRS & 28 & 0.810 & 0.821 & 0.810 & 0.987 & DRS \\
\hline 9 & 0.575 & 0.637 & 0.575 & 0.901 & IRS & 29 & 1.000 & 1.000 & 1.000 & 1.000 & CRS \\
\hline 10 & 0.714 & 0.716 & 0.714 & 0.998 & DRS & 30 & 1.000 & 1.000 & 1.000 & 1.000 & CRS \\
\hline 11 & 0.608 & 0.884 & 0.608 & 0.688 & IRS & 31 & 0.808 & 0.809 & 0.808 & 0.988 & IRS \\
\hline 12 & 0.535 & 0.611 & 0.535 & 0.875 & IRS & 32 & 0.936 & 1.000 & 0.936 & 0.936 & IRS \\
\hline 13 & 0.503 & 0.535 & 0.503 & 0.940 & IRS & 33 & 1.000 & 1.000 & 1.000 & 1.000 & CRS \\
\hline 14 & 1.000 & 1.000 & 1.000 & 1.000 & CRS & 34 & 0.929 & 0.938 & 0.929 & 0.990 & DRS \\
\hline 15 & 1.000 & 1.000 & 1.000 & 1.000 & CRS & 35 & 0.897 & 0.902 & 0.897 & 0.995 & DRS \\
\hline 16 & 1.000 & 1.000 & 1.000 & 1.000 & CRS & 36 & 0.917 & 0.919 & 0.917 & 0.997 & IRS \\
\hline 17 & 0.824 & 0.848 & 0.824 & 0.972 & IRS & 37 & 1.000 & 1.000 & 1.000 & 1.000 & CRS \\
\hline 18 & 0.997 & 1.000 & 0.997 & 0.997 & IRS & 38 & 1.000 & 1.000 & 1.000 & 1.000 & CRS \\
\hline 19 & 0.911 & 0.917 & 0.911 & 0.993 & IRS & 39 & 1.000 & 1.000 & 1.000 & 1.000 & CRS \\
\hline 20 & 0.876 & 0.876 & 0.876 & 1.000 & CRS & 40 & 1.000 & 1.000 & 1.000 & 1.000 & CRS \\
\hline
\end{tabular}

